\title{
Recenzja
}

\section{Parlamentarny system rządów. Teoria i praktyka, red. Tadeusz Mołdawa, Jarosław Szymanek, Michał Mistygacz, Wydawnictwo Elipsa, Warszawa 2012, ss. 318}

Parlamentaryzm to system rządów charakterystyczny dla współczesnej demokracji, w którym, zgodnie z koncepcją podziału władz, parlament uchwala ustawy i sprawuje kontrolę nad rządem. Na temat parlamentaryzmu napisano dużo w różnych aspektach, od przedstawienia systemów poszczególnych krajów po ogólne naukowe rozważania.

W uproszczeniu, cytując za wstępem, recenzowane opracowanie można streścić jako przedstawienie systemu parlamentarnego okiem prawników konstytucjonalistów oraz politologów, jako „spojrzenie całościowe, pokazujące prawdziwą istotę systemu, jego konstytucyjne i polityczne determinanty, logikę działania i wreszcie zmiany jakie są jego udziałem” (s. 11). Teksty zamieszczone w książce pochodzą głównie od uczestników zjazdu katedr i zakładów prawa konstytucyjnego, którego organizatorem był Zakład Systemów Politycznych Instytutu Nauk Politycznych Uniwersytetu Warszawskiego.

Przedmiotowe opracowanie jest niewątpliwe ciekawym tematem jako globalne spojrzenie na powstanie, rozwój i ukształtowanie systemów parlamentarnych na świecie, od czasów Monteskiusza poprzez francuską Kartę konstytucyjną z 1814 r. po Konstytucję Rzeczypospolitej Polskiej oraz integrację europejską i jej wpływ na parlamentaryzm.

Książka składa się z 4 rozdziałów, kolejno przedstawiających definicję pojęcia parlamentaryzmu, polskie dzieje parlamentaryzmu, europejskie modyfikacje systemu oraz „wielowariantowość systemu”, czyli uwagi na temat „odmian” systemu. Na książkę złożyło się 17 opracowań politologów oraz konstytucjonalistów. Swoje spostrzeżenia i uwagi na temat systemu przedstawili: prof. Andrzej Antoszewski, dr Michał Bożek, dr Ryszard Chruściak, dr Marek Jarentowski, prof. Jerzy Jaskiernia, prof. Maria Kruk, prof. Ryszard M. Małajny, dr Anna Materska-Sosnowska, dr Piotr Mikuli, dr Michał Mi- 
stygacz, dr Tadeusz Mołdawa, dr Ryszard Piotrowski, prof. Paweł Sarnecki, dr Jarosław Szymanek, dr Krzysztof Urbaniak, dr Krzysztof Wojtyczek, dr Krzysztof Wójtowicz.

Pierwsza część opracowania zajmuje się próbą zdefiniowania (konceptualizacją) sytemu parlamentarnego oraz przedstawieniem jego historycznego rysu. W praktyce oprócz pierwszego opracowania prof. Marii Kruk Wprowadzenie do problematyki parlamentarnego sytemu rząów dwa pozostałe opracowania: Parlamentaryzm jako przestrzeń rywalizacji międzypartyjnej autorstwa A. Antoszewskiego oraz Rozdział władzy w systemie parlamentarnym Ryszarda M. Małajny - to bardziej rozważania na temat sytemu parlamentarnego jako pola działania władz i partii politycznych. Dla mnie jako prawnika bardziej czytelne są rozważania o systemie parlamentarnym jako określonej formie rządów niż rozważania politologa traktującego parlamentaryzm jako „określony typ przestrzeni politycznej, w ramach której toczy się rywalizacja o władzę, a ściślej biorąc o utworzenie, utrzymanie lub obalenie gabinetu. Podmiotami tej rywalizacji są partie polityczne, których główna funkcja sprowadza się do uczestnictwa w wyborach i do usuwania kandydatów na stanowiska publiczne" (A. Antoszewski, Parlamentaryzm jako przestrzeń rywalizacji międzypartyjnej, s. 45). Politologiczna definicja parlamentaryzmu - jak pisze Autor - nie może opierać się wyłącznie na przepisach prawa (Konstytucji), ale musi brać pod uwagę również pozainstytucjonalne uwarunkowania rywalizacji politycznej. Autor opisuje parlamentaryzm jako narzędzie utrzymania władzy, jej utraty oraz jako możliwość przejęcia władzy i niwelowania napięć.

Zatrzymam się przy opracowaniu prof. Marii Kruk, w którym w sposób czytelny i interesujący Autorka dokonała zarówno wprowadzenia, jak i podsumowania, czym był i jest obecnie system parlamentarny na świecie. Na zakończenie Autorka cytuje odpowiedź Solona, który na pytanie o najlepszy system rządu odrzekł: „powiedz mi najpierw dla jakiego kraju, dla jakiego ludu i w jakim momencie jego historii”. Opracowanie jest syntetyczną analizą systemu parlamentarnego od zarania dziejów: od Monteskiuszowskiego modelowego systemu dwuizbowego parlamentu z wyszczególnioną rolą izby wyższej, kolejno przedstawieniem odmiennego pojmowania systemu parlamentarnego we Francji, aż po opisanie podstawowych cech parlamentaryzmu z uwzględnieniem jego ewolucji. 
Drugi rozdział - Polska aplikacja sytemu parlamentarnego - zawiera dwa opracowania, w których autorzy (J. Jaskiernia i J. Szymanek) przedstawiają polski system parlamentarny, rolę parlamentu, zadania, uwarunkowania konstytucyjne, rolę drugiej izby parlamentu, elementy racjonalizacji sytemu. W swoim opracowaniu Parlamentaryzm III RP: aksjologia konstytucyjna a dylematy praktyki ustrojowej J. Jaskiernia we wnioskach końcowych stawia tezę o możliwości zmiany w prawodawstwie polskim w kierunku systemu mieszanego i odejścia od klasycznej zasady proporcjonalności. Autor podkreśla, iż zmian należy dokonywać ostrożnie, bowiem zbyt radykalne ograniczenie systemu proporcjonalnego może znacząco osłabić proces konsolidacji sytemu partyjnego. Druga teza prezentowana przez autora dotyczy zbalansowaniu uprawnień Senatu. W tym miejscu należy zgodzić się z autorem, iż słaby model ustrojowy Senatu i jego znikoma de facto rola nie sprzyjają pozytywnemu postrzeganiu dorobku tej izby. Podzielam pogląd autora o konieczności ostrożnego podchodzenia do teorii likwidacji bikameralizmu. Autor podkreśla motywacje „taktyczno-polityczne”, podczas gdy ja patrzę na Senat jako ogniowo w polskim procesie ustawodawczym i z ubolewaniem dostrzegam niewielką rolę Senatu w tym zakresie.

Interesująca jest część opracowania dotycząca wpływu traktatu z Maastricht na współczesne systemy parlamentarne. W dwóch tekstach Autorzy przedstawiają, jak integracja europejska wpłynęła na ustroje państw członkowskich (K. Wojtyczek) oraz jaką rolę odgrywają parlamenty narodowe w świetle postanowień traktatów europejskich (K. Wójtowicz).

W pierwszym tekście - Oddziaływanie integracji europejskiej na ustroje państw członkowskich Unii Europejskiej - K. Wojtyczek próbuje odpowiedzieć na pytanie, czy Unia Europejska ogranicza swobodę działania i funkcjonowania państwa, które przekazuje cześć swoich kompetencji na rzecz Unii. Autor, wychodząc z założenia, że Unia miała służyć państwom członkowskim i realizować cele wyznaczone przez te państwa, analizuje problemy, jakie integracja przyniosła ustrojom państw członkowskich. Wskazuje, iż integracja sprzyja pogłębianiu deficytu demokracji, deparlamentaryzacji i judycjalizacji ustroju państwowego. W podsumowaniu Autor stawia pytania o to, jak integracja europejska wpłynęła na średnią długość trwania rządów, czy sprzyja kryzysom politycznym w państwach członkowskich, czy też może ich stabilizacji. Niestety w opracowaniu zabrakło próby udzielenia odpowiedzi na te pytania, a ogólne podsumowanie sprowadza się do wniosku, 
zgodnie z którym „ustalanie konsekwencji ustrojowych państwa w Unii Europejskiej przez wiele lat pozostanie jednym z zasadniczych wyzwań badawczych dla współczesnego ustrojoznawstwa" (s. 183).

Druga część, autorstwa Krzysztofa Wójtowicza, poświecona jest roli parlamentów narodowych w świetle zapisów Traktatu o Unii Europejskiej, czyli roli parlamentów narodowych w prawidłowym funkcjonowaniu Unii. Autor podkreśla, iż rola i zadania parlamentów narodowych $\mathrm{w}$ funkcjonowaniu Unii Europejskiej może znacząco zmniejszyć deficyt demokracji w Unii. Rola parlamentów narodowych w procesie stanowienie prawa Unii jest istotna $\mathrm{z}$ uwagi na przenikanie się prawa wspólnotowego do krajowych porządków prawnych. Z prawnego punktu widzenia zabrakło określenia charakteru tego przenikania i wpływu prawa wspólnotowego na konkretny, przykładowo polski porządek prawny.

Ostatni rozdział, zatytułowany Wielowariantowość systemu parlamentarnego, poświęcony został między innymi systemowi parlamentarnemu w Niemczech z ,jego monarchicznymi korzeniami”, brytyjskiemu systemowi parlamentarnemu oraz systemowi mieszanemu. Jest to próba przedstawienia oraz ewaluacji różnorodnych odmian systemu parlamentarnego. Autor opracowania Monarchiczne korzenie systemu parlamentarnego w Niemczech - M. Bożek - analizuje system parlamentarny Niemiec z wyeksponowanym stanowiskiem kanclerza, wychodzący z analizy porządku prawnego sięgającego korzeniami czasów Republiki Weimarskiej.

Z kolej P. Mikuli przedstawia westminsterski system polityczny, czyli „klasyczny system parlamentarny”, cytując za S. Gebethnerem kanony systemu: dualistyczna egzekutywa, zasada indywidualnej odpowiedzialności politycznej ministrów oraz odpowiedzialność solidarna rządu przed parlamentem, możliwości rozwiązania parlamentu przez egzekutywę. Autor wskazuje jednak kilka dodatkowych wyróżników brytyjskiego systemu - neutralna politycznie głowa państwa, monarcha jako człon parlamentu, fachowa służba cywilna.

J. Szymanek w swoim opracowaniu dotyczącym premierowskiej odmiany systemu parlamentarnego wskazuje, iż system parlamentarny to rodzina systemów, które muszą spełniać jakieś wzorce, przy czym są na tyle odmienne, że tworzą „prawdziwa paletę rozwiązań czasami mocno oddalonych od właściwego podręcznikowego modelu parlamentarnego" (s. 237). Zdaniem Autora system parlamentarny jest systemem niesłychanie giętkim i elastycz- 
nym, a jego wielowariantowość stanowi jego immamentną cechą. Autor wskazuje, że skoro kanwą systemu parlamentarnego jest „niepełny albo niekonsekwentny podział władz, to tak jak ten podział może być, i w praktyce jest, niepełny i niekonsekwentny, dopuszczając różnego rodzaju odstępstwa od niego, tak różne mogą być, i w rzeczywistości są, systemy parlamentarne" (s. 238). Autor wskazuje, jak różne są systemy polityczne w Portugalii, Belgii, Niemczech, Finlandii, na Węgrzech czy w Rumunii, pomimo iż one wszystkie odwołują się do systemu parlamentarnego. Autor podkreśla, iż często przyjmuje się, iż naczelną i najważniejszą cechą systemu parlamentarnego jest zasada politycznej odpowiedzialności rządu przed parlamentem. Analizując brytyjski system parlamentarny, Autor wskazuje, iż ten współczesny system odszedł daleko od systemu parlamentarnego w kierunku sytemu rządów tzw. premierowskich, w których to premier kumuluje w swoich rękach funkcję rządzenia.

Poruszane w książce zagadnienia, mimo iż powiązane tematycznie, są bardzo różnorodne. Opracowanie stanowi ciekawe spojrzenie na systemy parlamentarne we współczesnym świecie oraz jego pierwotne źródła. Ukazuje jak wieloobrazowy jest to system, którego ewolucja uwarunkowana jest m.in. zmianami zachodzącymi w świecie politycznych przekształceń. System ten uzależniony jest mocno od systemów partyjnych i lokalnych (krajowych) uwarunkowań, które doprowadziły do wytworzenia różnych modeli - od modelu francuskiego (typowy parlamentaryzm) do modelu włoskiego czy szwedzkiego. Opracowanie z pewnością uzasadnia podnoszoną wielokrotnie tezę, iż system parlamentarny jest zmienny, trudny do zdefiniowania oraz iż jest swoistym fenomenem ustrojowo-politycznym, który od kilku stuleci nie został zdetronizowany przez żaden inny model i zachowuje zdolność adaptacji, a także odradzania się w odmiennych, często niepowtarzalnych warunkach różnych państw (M. Kruk, s. 40).

Lektura niniejszego opracowania wywołała u mnie wrażenie, iż całość stanowi przypadkowy zbiór referatów poświeconych wspólnemu tematowi. Autorzy - wybitni specjaliści w swoich dziedzinach - wyrazili w referatach swoje poglądy, niemniej jednak cel pracy, tj. „spojrzenie całościowe, pokazujące prawdziwą istotę systemu (...)", nie został osiągnięty.

Małgorzata Terlikowska (Kancelaria Prezesa Rady Ministrów) 